during the International Colour Vision Conference, show that some loss of blue sensitivity may occur in the central fovea, but we have not suggested that the fovea is blind to these radiations.

Koenig's interpretation of the dichromatism was no doubt in error. It is, however, important not to condemn the experiments along with the theory, and I have no doubt at all about the fundamental soundness of Koenig's original observation of foveal tritanopia, nor of Willmer's re-discovery of the phenomenon.

W. D. WRIGHT

Imperial College of Science and Technology, London, S.W.7.

${ }^{1}$ Willmer, E. N., Nature, 153, 774 (1944).

${ }^{2}$ Willmer, E. N., and Wright, W. D., Nature, 156, 119 (1945).

'Thomson, L. C., and Wright, W. D., J. Physiol., 105, 316 (1947).

\section{Visual Cells of the Guinea Pig}

THe statement of Granit ${ }^{1}$ that the guinea pig has a "pure rod eye" calls for comment. Franz" referring to a paper of his own published in 1909, says that cones are missing from the retina of the guinea pig. $\mathrm{Ovio}^{3}$ admits the presence of a few cones. Kolmer ${ }^{4}$ describes cones and rods. He makes the significant remark that observation prior to his own had been made on poorly fixed material. Rods are four to five times as numerous as cones, and he comments on the clear vacuoles at the peripheral end of the cone myoids.

Preparations of my own made nearly ten years ago confirm the findings of Kolmer. Neither the cornea nor the lens is as large as one would expect in an eye populated only by rods. The ratio of nuclei in the outer layer to that of the bipolars is four, or at the most five, to three (excluding the nuclei of Müller's fibres), a much lower ratio than one expects in a pure rod retina. In the dog it is twelve to four at least, and in a jerboa mouse (Notomys cervinus Gould) sixteen to five. These ratios are only approximate, but are an indication of the amount of summation of impulses in the retinæe of these two eyes rich in rods. The eye of the dog is larger than that of the guinea pig, that of the Jerboa mouse smaller. Cupshaped vesicular areas in the outer molecular layer of the guinea pig's retina suggest that some of the visual cells have dendritic foot-pieces. In my own preparations the cone myoids project beyond those of the rods. The tip of the distal segment of the cone is enveloped in a process of the pigment epithelium, and in areas where the visual cells have lost touch with the pigment epithelium, the cones do not part company with it as easily as do the rods. This enveloping of the tip of the cone has been commented on in the human retina by Walls ${ }^{5}$ and Kolmer ${ }^{6}$.

To the histologist, the retina of the guinea pig is certainly not 'pure rod'.

\section{St. Vincent's Hospital, Melbourne. July 8.}

'Granit, R., J. Physiol., 103, 103 (1944).

"Franz, V., "Vergleichende Anatomie des Wirbeltierauges", in "Handbuch der Vergleichende Anatomie der Wirbeltiere", 2, pt. 2, 1,238. (Vienna: Bolk/Goppert/Kallius/Luboseh, 1934.)

"Ovio, J., “Anatomie et physiologie de l'œil dans la série animale", 139 (Paris, 1927).

- Kolmer, W., "Vergleichende Anatomie der Netzhaut", in "Handbuch der Mikroskopisehen Anatomie des Menschen", 3, pt. 2. 321-326 (Fig. 259), 420-21 (Berlin, 1936).

${ }^{\circ}$ Walls, G. L., Arch. Ophthal., 12, 1918 (1934).

'Kolmer, W., ibid., 318 (Fig. 251 A).

\section{Sound Emitted by Dolphins}

DURING a cruise in the Mediterranean last year on board the Swodish research ship the Skagerak, I happened to notice that the dolphins (Delphinus delphis) uttered sounds that were quite audible on board the ship, though the dolphins were swimming one or two metres below the surface. The sounds may be described as short, rapidly repeated squeaks rather like those produced by fighting or playing mice. As I had many opportunities of listening to the sounds, sometimes with the ship at rest in calm weather, and had several other persons verify the observation, there can be no doubt as to the ability of the dolphins to produce audible sounds.

Oceanographic Institute, Gothenburg.

B. KullenberG

\section{Elemental Nomenclature}

IT may be presumptuous for a zoologist to speak to a chemical question. However, the points raised by Vallarta and Arnaiz y Freg and by Webb in Nature of August 12, pp. 163-64, are on all fours with problems of nomenclature familiar to biologists. Del Rio's erythronium was validly published and, from a zoological point of view, his subsequent disavowal was an ineffective act. The chemists are well advised in being cautious about the unreasoning application of the rule of priority. Since the number of elements seoms unlikely to be much in excess of a hundred, the problem is quite simple compared with the handling of some 200,000 generic names of animals. Hence the homonymy between two uses of plutonium causes no confusion. Perhaps a new rule might read that if a name has had no employment for fifty years, whether or not withdrawn by its author, it shall become a nomen vacuum, with the recommendation that such names should not be re-used with a new meaning. Finally, this rule or any other nomenclatorial rule should not be applied retroactively, since there is an implied contract between the rules and the public that a change in the rules shall not render a previously legal usage illegal. The lawyer calls this stare decisis.

Department of Biology,

Charles H. Blake

Massachusetts Institute of Technology,

Cambridge, Massachusetts. Sept. 2.

\section{"Miracles"}

IN my recent review of Mr. C. S. Lewis' book on "Miracles", I wrote that what are described as miracles "occur most freely in periods when critical skill is least". From Mr. E. V. Burke, writing from 27 The Crescent, London, S.W.13, I have received references to the following books on cures recorded at Lourdes: F. le Bac, "Medical Proof of the Miraculous, a Clinical Study" (1922), and G. Bertrin, "Lourdes, its Apparitions and Cures" (English translation by Lady Gibbs), and the Catholic Medical Guardian, 1933-34 (case of Pierre de Rudder, broken leg cured instantaneously), which may not be generally known.

I have only to add that I did not say that such cures do not occur when (or where) critical skill is adequate; and Mr. Burke himself writes that "many claimants to miracles are completely rejected" at Lourdes.

Oxford.
JoHN L. MYres 